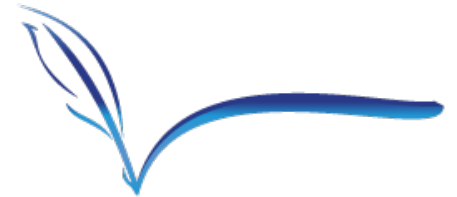

SSAD

Stratejik ve Sosyal Araştırmalar Dergisi

ISSN 2587-2621

Cilt 5, Türk-Yunan İlişkileri Özel Sayısı | Volume 5, Special Issue: Turkish-Greek Relations, 30 Ağustos/30 August 2021 sisaddergi@gmail.com

Makale Türü/Article Type: Araştırma/Research

Makale Gönderim Tarihi/Received Date: 09.04.2021

Makale Kabul Tarihi/Accepted Date: 22.06.2021

DOI: $10.30692 /$ sisad.912496

\title{
NÜFUS MÜBADELESİ VE BATI TRAKYA TÜRKLERİ
}

\section{Population Exchange and Turks of Western Thrace}

\author{
Nilüfer ERDEM \\ Doç. Dr. \\ İstanbul Üniversitesi, Atatürk İlkeleri ve İnkılap Tarihi Enstitüsü \\ ORCID ID: 0000-0003-1393-7655 \\ nilerdem@istanbul.edu.tr
}

Atıf/Citation: Nilüfer Erdem (2021), "Nüfus Mübadelesi ve Batı Trakya Türkleri”, Stratejik ve Sosyal Araştırmalar Dergisi Türk-Yunan İlişkileri Özel Saylsı, C. 5, 30 Ağustos 2021, s.139-151.

Öz: Mübadele dışında tutulmaları, Batı Trakya Türklerinin mübadeleden kaynaklı problemler yaşamalarını engellememiştir. Bu problemlerin ana sebebi, bölgeye Yunan idaresi tarafından kapasitesinin çok üzerinde Rum mübadil yerleştirilmesidir. Mübadil yerleştirilmesi Batı Trakya'daki demografik, ekonomik ve sosyal dengeleri bozacak şekilde gerçekleşmiştir. Devamında Türklere ait arazilerin bir kısmı istimlâk edilerek, bu araziler üzerine mübadiller için mahalle ve köyler inşa edilmiştir. 1930 Türk-Yunan dostluğuna kadar bölge Türkleri durumlarındaki birtakım belirsizlikleri de göğüslemek zorunda kalmışlar ve içlerinden bazıları yeni koşullara ayak uyduramayarak Türkiye'ye göç etmeyi tercih etmişlerdir. Makalemizin amacı, Rum mübadillerin yerleştirilmesi sonrası Batı Trakya Türklerinin yaşadıkları sıkıntılara ve bölgedeki değişimlere 1şık tutmaktır. Bunun için ana kaynaklarımız, o dönem bölgede yayınlanmış olan "Yeni Adım" gazetesi ile birlikte Yunanistan Azınlıklar Müfettişi Stilianopulos ve Trakya Genel İdarecisi Floryas’ın, Benaki Müzesi Eleftherios Venizelos Arşivi’nde yer alan raporlarıdır.

Anahtar Kelimeler: Nüfus Mübadelesi, Batı Trakya, Lozan, Göç, Yunanistan.

\begin{abstract}
The fact that they were excluded from the exchange did not prevent the Turks of Western Thrace from experiencing problems caused by the exchange. The main reason for these problems is that Greek immigrants were placed by the Greek administration in the region far above the capacity. The settlement of the immigrants took place in a way that disrupted the demographic, economic and social balances in Western Thrace. In the continuation, some of the lands belonging to the Turks were expropriated and neighborhoods and villages were built for the immigrants on these lands. Until the 1930 Turkish-Greek friendship, the Turks of the region had to face a number of uncertainties in their situation and some of them chose to emigrate to Turkey, unable to keep up with the new conditions. The aim of our article is to shed light on the difficulties experienced by the Turks of Western Thrace after the exchange and the changes in the region. Our main sources for this are the reports of Stilianopoulos, the Inspector of Minorities of Greece, and Floryas, the General Administrator of Thrace, together with the newspaper "Yeni Adım", which was published in the region at that time. These reports are placed in the Eleftherios Venizelos archive of the Benaki Museum.
\end{abstract}

Keywords: Population Exchange, Western Thrace, Lausanne, Migration, Greece. 


\section{GİRIȘ}

Meriç (Evros) Nehri ile Türkiye'den, Mesta Karasu (Nestos) Nehri ile Makedonya'dan ayrılan Batı Trakya Bölgesi’nin kuzeyindeki Rodop Dağları Bulgaristan ile sınırı teşkil etmekte, bölgenin güneyinde Ege Denizi yer almaktadır. Bölge Meriç (Evros), Rodop ve İskeçe (Ksanthi) illerinden oluşmaktadır. Meriç İli’nin merkezi Dedeağaç (Aleksandrupolis), Rodop İli'nin merkezi Gümülcine (Komotini) ve İskeçe İli’nin merkezi İskeçe (Ksanthi)dir. Bölge Türkleri tarafından Rodop Dağlarının eteklerinden denize kadar inen düzlük bölge Ova, burayla Rodop Dağları arasında kalan kısım Yaka, oranın da kuzeyindeki dağlık bölge Cebel ya da Balkan Kolu olarak anılmaktadır (Alp, 1995, s. 614).

Batı Trakya bölgesi, üç asır süren Osmanlı çöküş döneminin sonunda ilk Türk cumhuriyetinin kurulduğu topraklardır. Yeşil, siyah ve beyaz renklerden oluşan ve köşesinde Türklük ve bağımsızlı̆̆ 1 simgeleyen bir ay yıldız barındıran "Garbi Trakya Hükümet-i Müstakilesi”nin bayrağındaki siyah Balkanların kaybedilmesinden duyulan matemin, yeşil ise ümidin simgesidir (Bıyıklığlu, 1955, s. 73-89; Gencer ve Özel, 2001, s. 43-44). Milli Marşı'nda “Ey Batı Trakyalı asil Türk çocuğu ne mutlu sana / Sen hayat verdin kanınla milli kurtuluş savaşına / Yüce kahramanlığın nakşsedildi cihanın her yanına / Selam duruyor bütün milletler senin şu milli bayrăgına" dizeleri dikkat çekmektedir (Cihan, ty, s. 126). İkinci Balkan Savaşı'nın karmaşık ortamında tarih sahnesine çıkmış olan bu yeni Türk devleti, Osmanlı Devleti'nin 29 Eylül 1913'te Bulgaristan ile imzalamış olduğu İstanbul Antlaşması sonrası kendini feshetmek zorunda kalmıştır (Erdem, 2014, s. 80-82). Bu gelişmeden sonra bölge Bulgarların eline geçmiş ve 1918 yılına kadar Bulgar egemenliğinde kalmıştır. Ancak müttefiklerle Bulgaristan arasında imzalanan Neuilly (Nöyyi) Antlaşmasının 48. maddesine dayanılarak Batı Trakya'nın kuzey dağlık kısmı Bulgaristan'a bırakılırken geri kalan kısmı, yani Karaağaç, Dimetoka, Sofulu, Dedeağaç, Gümülcine ve İskeçe kazaları Müttefiklerarası Trakya Hükümeti adı altında Fransız askeri makamlarının idaresine verilmiştir (Bıyıklığlu, 1955, s. 183-184).

Diğer taraftan bulunduğumuz coğrafyada sınırları, siyasi ve sosyal yapıyı değiştiren Birinci Dünya Savaşı'nda Osmanlı Devleti'nin çeşitli cephelerinde savaşan Batı Trakyalı askerler olmuştur (Erdem, 2018, s. 104-105). Türkler için savaş 30 Ekim 1918 tarihli Mondros Ateşkes Antlaşması ile sona ermemiş, tam tersine bu ateşkes yeni bir mücadelenin fitilini ateşlemiştir. Genellikle Müdafaa-i Hukukçu milletvekillerinden oluşan Son Osmanlı Meclisi Mebusanı'nda 1920 yılı Ocak'ında okunan ve sonrasında kabul edilen, Türk milletinin razı olabileceği asgari koşulları içeren Misak-1 Milli'nin şartlarından biri Batı Trakya ile ilgilidir ve bölgenin hukuki durumunun özgürce yapılacak halkoylaması ile belirlenmesini istemektedir (Budak, 2014, s. 176). Ne var ki Batı Trakya 1920 Mayıs'ında Yunan ordusu tarafindan işgal edilmiştir (Bıyıklığlu, 1955, s. 308-309). 1920 yazında Yunan ordusunun Milne hattını aşarak Balıkesir ve Bursa, ayrıca Edirne ile birlikte Doğu Trakya'yı da eline geçirdiğini hatılatmamız gerekir (Gazi Mustafa Kemal, 1999, s. 619; Mazarakis Enian, 2003, s. 258-260).

Mondros Ateşkes Antlaşması'ndan sonra işgalci güçlere karşı gerçekleştirdiği özgürlük ve bağımsızlık mücadelesini Türk milleti zaferle neticelendirmeyi başarmış ve İsviçre'nin Lozan şehrinde toplanan barış konferansında, Birinci Dünya Savaşı'nı kaybeden devletlerden sadece Türkiye, kendisi hakkında verilen kararları tersine çevirerek yeni bir barış için müttefiklerle eşit şartlarda masaya oturmayı başarmıştır. Konferanstaki hedefi Misak-1 Milli'yi gerçekleştirmek olan Türkiye'nin baş delegesi İsmet Paşa, ilgili oturumlarda Batı Trakya konusunu gündeme getirerek bölgenin geleceğinin halk oylaması ile saptanmasını istemiştir. Ancak İsmet Paşa'ya, müttefiklerin Türkiye'ye bu hakkı tanımaya eğilimli olmadıkları ifade edilmiştir (İnönü, 1987, s. 65-68). Lozan Antlaşması ile Yunanistan'a bırakılan Batı Trakya bölgesinde (Soysal, 2000, s. 
95) yaşayan Müslümanlar, 30 Ocak 1923 günü imzalanan "Türk ve Rum' Nüfusun Mübadelesine İlişkin Sözleşme ve Protokol" uyarınca İstanbul Rumları ile birlikte mübadele, yani karşı1ıklı zorunlu göçün dişında tutulmuşlardır (Soysal, 2000, s. 185).

Mübadele kararının alınmasında, Yunanistan'ın Anadolu Bozgunu sonrasında pek çok Rum, bunun yanında kimi Ermeni, Süryani ve Çerkez nüfusun akınına uğraması neticesinde sosyal, ekonomik ve idari sorunlarla karşı karşıya kalmasının etkisi vardır. Limanlar ve kasabalardaki depolarda, sığınak ve çadırlarda üst üste yaşamakta olan bu göçmenlerin yerleştirilebilmeleri için topraklarında yaşayan Müslüman Türklerin Türkiye'ye gönderilmeleri, şüphesiz Yunanistan'1 rahatlatacaktı. Türkiye ise kurtuluş mücadelesinin ardından başlayan yeni dönemde yanıp yıkılan yerlerin onarımını ve hareketlilik gösteren nüfusunun yerleştirilmesini temin etmeye çalışmaktaydı. Rumların bıraktıkları toprakların, zeytinliklerin ve bağların işlenmesi, ürünlerinin toplanması Türkiye açısından önemliydi (Arı 2014, s. 22-23). Buna rağmen karar alındıktan sonra başta mübadillerin nakli konusu olmak üzere pek çok konunun çözülmesi gerekmiştir (Arı, 1991, s. 26).

Türkiye'ye gelen mübadillerin \%58'i Marmara Bölgesine, \%13'ü Ege Bölgesi’ne, \%11’i Karadeniz Bölgesi'ne ve \%10'u İç Anadolu Bölgesine yerleștirilmişlerdir. Türkiye'de en az mübadil yerleştirilen bölgeler Doğu ve Güneydoğu Anadolu Bölgeleri olmuştur (Bayındır Goularas, 2012, s. 132-134). Yunanistan'da ise mübadiller ağırlıklı olarak Makedonya ve Merkez Yunanistan'a yerleştirilmişlerdir. Bunu Batı Trakya, Ege Adaları, Tesalya, Girit ve Mora Yarımadası izlemiştir (Pavlidis, 1997, s. 22-23).

Makalemizin amacı, Batı Trakya'ya yerleştirilen Rum mübadiller sonrasında bölge Türklerinin yaşadıkları sıkıntılara ve bölgede söz konusu olan değişikliklere 1şık tutmaktır. Bunun için ana kaynaklarımız, o dönem bölgede yayınlanmış olan Mehmet Hilmi'nin "Yeni Adım" gazetesi ile birlikte Yunanistan Azınlıklar Müfettişi Stilianopulos ve Trakya Genel İdarecisi Floryas'ın, Benaki Müzesi Eleftherios Venizelos Arşivi'nde yer alan raporlarıdır. Biri yerel bir gazeteci, diğerleri Yunan devlet memurları olmalarına rağmen kaleme aldıkları yan yana getirildiğinde, mübadele sonrası Batı Trakya'ya ait tablo çok daha net bir şekilde ortaya çıkmaktadır.

\section{Mübadil Yerleştirilmesinin Batı Trakya'nın Demografik ve Sosyal Yapısına Etkileri}

Osmanlı belgeleri, bölgenin nüfusunun çoğunlukla Müslüman Türklerden oluştuğunu ortaya koymaktadırlar. Örneğin 1903'te Batı Trakya'nın toplam nüfusunun \%71,50'si (255.102) Müslüman Türklerden oluşmaktadır. Geri kalan nüfusun \%16,19'u (57.878) Rum ve \%12,3’ü (44.181) Bulgar'dır. Balkan ve Birinci Dünya Savaşı esnasında yaşanmış olan tüm olumsuzluklara rağmen İsmet Paşa'nın Lozan'da Batı Trakya nüfusuna ilişkin sunmuş olduğu verilere bakıldığında, 191.691 olan bölge nüfusunun 129.118'inin Türklerden ve ancak 33.904'ünün Rumlardan oluştuğu görülmektedir (Bıyıklığlu, 1955, s. 486). Yunan yetkilileri tarafından kapasitesine oranla fazla sayıda mübadilin yerleştirilmesi Batı Trakya'nın demografik, bunun yanında sosyal, kültürel ve ekonomik yapısını tamamıyla değiştirmiştir. 1928 nüfus sayımı verileri Batı Trakya'nın 303.171 olan nüfusunun 107.607'sinin göçmen olduğunu ortaya koymuştur. Bir diğer ifadeyle bölge nüfusunun yaklaşık üçte birini Hellenler teşkil etmeye başlamışlardır (Eren, 1995, s. 56; Pavlidis, 1997, s. 22).

Batı Trakyalı Türklerin yerleştirilen mübadiller sebebiyle yaşadıkları sorunlar Mehmet Hilmi'nin "Yeni Adım" gazetesinde ayrıntılı ve içten bir şekilde ele alınmış, bir anlamda Yeni Adım 1920'li yıllarda Batı Trakya Türklerinin dili olmuştur. 1902 yılında Sofulu'nun Babalar Köyü'nde doğmuş olan Mehmet Hilmi, Edirne Lisesi ve Öğretmen Okulu'na devam etmiş, Batı Trakya Türklerine ait okullarda öğretmenlik yapmıştır. Lozan Antlaşması'ndan sonra Batı

\footnotetext{
${ }^{1}$ Çalışmamızda Ortodoks olan, Yunanca konuşan Osmanlı ve daha sonra Türk uyruklu olan azınlık mensuplarını "Rum" ifadesiyle andık. Yunanca konuşan, Ortodoks Yunanistan vatandaşlarını anmamız gerektiğinde "Yunan" kelimesini kullandık. Bu ikisinin iç içe geçtiği durumlarda "Hellen" sözcügü tercih ettik.
} 
Trakya'da "Yeni Ziya", "Yeni Yol" ve "Yeni Adım" gazetelerini çıkarmış ve 1931 yılında vefat etmiștir (Eren, 1995, s. 161-162; Anı ve Hikâyeleriyle Mehmet Hilmi, 2021, s. 12). Mehmet Hilmi otuz yıl dahi sürmeyen kısacık ömründeki yoğun mesaisini, "Biz yalnız Türk halkının refahına, saadetine, terakki ve tekâmülüne çalı̧̧mayı emel edindik" sözleriyle anlatmıştır (Yeni Adım, 3 Teşrinisani 1928, s. 1). Yunanistan'ın Makedonya bölgesindeki Türkler mübadele kararı sonrasında göç ettiklerinden dolayı bu bölgeye yerleştirilen göçmen sayısının dengeleri altüst edecek derecede büyük olmadığına, oysa göçmenlerin iskânı konusunu ele almış olanların Bat1 Trakya'nın Makedonya'dan asgari dört defa küçük bir bölge olduğunu gözden kaçırdıklarına işaret etmiştir (Yeni Adım, 11 Kanunusani 1930, s. 1). Mehmet Hilmi'ye göre Batı Trakya'ya göçmen yerleştirilmesi, adeta "[Yunan Hükümeti'nin] Batı Trakyalı Türkler üzerinde bir emel beslediği kanaatini verecek bir surette” gerçekleşmiştir (Yeni Adım, 10 Teşrinisani 1928, s. 1-2). Yoğun mübadilin yerleştirilmesi neticesinde bölgede 280 yeni göçmen yerleşim biriminin ortaya çıtığına bakarak, Mehmet Hilmi'nin bu tespitinde hatalı olduğunu söylemek zordur (Pavlidis, 1997, s. 27).

Diğer taraftan Yunanistan Azınlıklar Müfettişi Konstantinos Stilianopulos'un (Benaki Müzesi, Eleftherios Venizelos Arşivi, 251-27) raporları, Lozan Antlaşması'nın hemen sonrasındaki süreçte Batı Trakya Türklerinin durumuna dair ipuçları içermekte ve olguları bir Yunan yetkilinin gözünden aktarmaktadır. Raporlarda kaydedilenler Mehmet Hilmi’nin düştüğü notlarla yan yana getirildiklerinde, döneme ait tablo çok daha net bir şekilde ortaya çıkmaktadır. $\mathrm{Bu}$ raporların birinde Stilianopulos, mübadillerin yerleştirilmesinin ve kimi mülklere Yunan Devleti tarafından el konulmasının Batı Trakya Türklerinin yaşam koşullarını güçleştirdiğini ve savaş sonrası ilk dönemlerde yaşadıkları sertliklerin onları korkuttuğunu kabul etmektedir. Türklerin psikolojisini tanımlarken, "Gelecek için şüphe ve olayların kökten değişeceğine dair umutlar arasinda gidip gelmektedirler" cümlesini kullanmakta, Yunan idaresine güvenmediklerinin, zorunluluktan dolayı yazgılarına boyun eğdiklerinin altını çizmektedir (Benaki Müzesi, Eleftherios Venizelos Arşivi, 053-34-35).

İlk zamanlar Batı Trakyalı Türklerin evlerinin bazı odalarına Rum mübadiller yerleştirilmiş, ya da bazı hallerde Türkler bir evde toplanmaya ve kendi evlerini mübadillere birakmaya mecbur edilmişlerdir (Yeni Adım, 30 Eylül 1928, s. 1). Müslüman Türklerle Hıristiyan mübadillerin birlikte yaşamaktan doğan sıkıntıları ve iki grubun diyalog kurmaktaki zorlukları Stilianopulos'un da dikkatini çekmiş ve raporlarının birinde koşulların neticesi olarak Türklerin "kendi ayrı hayatlarına kapandıklarını" kaydetmiştir (Benaki Müzesi, Eleftherios Venizelos Arşivi, 053-36). Bu durumda Türkçe konuştuklarından dolayı evlerine Karamanlılar, yani Türk komşularından dinleri haricinde pek de farklı olmayan Orta Anadolulu Ortodokslar yerleştirilenlerin şanslı addedilmeleri gerekir. Zira muhafazakâr olarak niteleyebileceğimiz bölge Türkleri Yunanca bilmiyorlardı. Diğer taraftan bölgeye göçmen yerleştirilmesi ile birlikte kimi huzursuzluklar vuku bulmuştur. Hamitli, Kireççiler (Yeni Adım, 17 Teşrinisani 1928, s. 2), Misvaklı, Köseler, Gökçeler, Karapazarlı (Karapazarlar), Alıççılar, Seymen, Karagözlü ve Fener (Yeni Adım, 15 Mart 1930, s. 3) örneklerinde olduğu gibi baskına uğrayan köyler olmuştur. Ya da bazı mübadiller, göçmen köyleri ve mahalleleri ortaya çıtığ oldukları evi terk etmek istemeyebilmişlerdir.

Dimetoka'da Türk vakıflarına ait kimi dükkânlar, "şehre park lazım” gerekçesiyle yıkılmışlardır (Hüseyinoğlu ve İmamoğlu, 2017, s. 113). İskeçe'nin son derece kıymetli Pazaryeri mevkiinde ve Yenice kasabasında yer alan, el konularak üzerine göçmenler için evler ve işyerleri inşa edilen mezarlıklar, Yunan idaresinin Türk mallarına gerçekleştirdiği istimlâkler açısından çarpıcı örneklerdir. Gümülcine Müftüsü Nevzat Efendi kendisinden mezarlıkların istenmesine "Dinen Müslüman mezarlıkları satılamaz" yanıtını verse de, Gümülcine'deki bazı Türk mezarlıkları istimlak edilerek üzerlerine Hıristiyan çocukları için okul gibi birtakım inşaatlar gerçekleştirilmiştir (Yeni Adım, 14 Teşrinisani 1928, s. 1-2). Gümülcine'de, bugün üzerinde büyük parkın bulunduğu Namazgâh Mezarlığının istimlak kararı üzerine Müftü mahkemeye başvurduğunda, kendisine "Mezarlığın tapusu yok" yanıtı verilmiştir (Hüseyinoğlu 
vd., 2017, s. 86-87). Yunan idaresinin bu tip uygulamalarının, Batı Trakyalı Türklerin dini ve milli duygularını rencide ettiğini anlamak kolaydır. Kaldı ki Yunan hükümeti, Lozan Antlaşması'nın 42. maddesi uyarınca Batı Trakyalı Türklere ait camilerin ve diğer dinsel kurumların yanında mezarlıkların da koruyuculuğunu üstlenmiş bulunmaktadır (Soysal, 2000, s. 104). Esasen Türklere ait kimi mezarlıklar ve vakıf mallarının istimlak edilerek elde edilen arazinin farklı amaçlar için kullanılması, Yunanistan tarafından Lozan Antlaşması'nın da ihlalidir. Bu noktada Mehmet Hilmi, Batı Trakya Türklerinin 1923'ten sonra maruz kaldığ 1 zarar ve ziyanlar için tazminat almaları gerektiğini çeşitli vesilelerle dile getirmiştir. Bu talebi vatandaşın göçmenlere sunduğu hayvanı, tarlası, otu, samanı, zahiresi, yatağı, yorganı, çiftliği, otlağı ve evi ile ilgili olduğu kadar, aynı zamanda Türk cemaatlerinin istimlâk edilen vakıf mallarıyla da ilgilidir (Yeni Adım Gazetesi, 16 Teşrinisani 1929, s. 1; Yeni Adım, 20 Teşrinievvel 1928, s. 1; Yeni Adım, 25 Mayıs, 1929, s. 1).

\section{Mübadil Yerleştirilmesinin Batı Trakya'nın Ekonomisine Etkileri}

Gelen mübadillerle birlikte, bölgedeki Türk köylerinin etrafinda mübadil mahalleleri ya da köyleri ortaya çıkmaya başlamıştır. Örneğin 60 haneli Davutlu köyünün kuzeyinde 50 haneli bir göçmen köyü oluşturulunca Davutlu'nun tapulu arazisinin beş yüz dönümü göçmenlerin eline geçmiş ve koşullar tarla kira bedellerinin yükselmesine yol açmıştır (Yeni Adım, 3 Teşrinisani 1928, s. 2). Benzer şekilde 32 haneli Alıçç1lar köyü çevresine toplamları 230-240 haneyi bulan üç göçmen köyü inşa edilince, köyün otlaklarının ve arazilerinin büyük kısmı göçmenlere paylaştırılmıştır (Yeni Adım, 27 Teşrinievvel 1928, s. 2). Yine Gümülcine'ye çok yakın, koyun ve keçi sürüleriyle ormanlardan geçinen 60 haneli bir Türk köyü olan Semetli'de mübadele öncesi 4000 baş hayvan köyün otlağında rahatlıkla beslenebiliyorken, mübadeleden sonra aynı otlaklardan eskisi gibi yararlanılamadığından Türklerin sürüleri eksilmiştir (Yeni Adım, 3 Ağustos 1929, s. 4).

Mehmet Hilmi, Yeni Adım Gazetesi'nde yaşananlara, "Her Türk köyünün civarında bir, iki, hatta üç adet muhacir köyü kurulmuş, Türk köyünün üç misli, dört misli bir muhacir nüfus yerleştirilmiştir. Zaten Türklere kifayet etmeyen (yetmeyen) arazi, bu sefer bu kalabalık muhacir kitlesine de taksim edilince ve muhacirler hâkim bir vaziyette bulununca, Türk'ün ne tarlası kalmış, ne merası kalmış, netice itibariyle ne hayvanı kalmıştır" sözleriyle dikkat çekmeye çalışmıştır (Yeni Adım Gazetesi, 20 Teşrinievvel 1928, s. 1). Kaldı ki Muhacir Komisyonu Teşkilatı'nın yayınladığı istatistikler, göçmenler geldikten sonra sürülen toprak miktarının beşte iki oranında arttığını ortaya koymuştur. Açıktır ki bu sürülen fazladan arazi, Türklere ait otlaklardır (Yeni Adım, 11 Kanunusani 1930, s. 1).

Stilianopulos döneme ait raporlarının birinde, otlakların darlığı ve köylerin etrafına göçmen köylerinin ya da mahallelerinin kurulması sebebiyle topraksız kaldıklarından dolayı Batı Trakyalı Türklerden şikâyetler aldığını kaydetmektedir (Benaki Müzesi, Eleftherios Venizelos Arşivi, 053-34-35). Bu şikâyetleri yorumlayabilmek için, bölgenin bir çiftçi memleketi, bir diğer ifadeyle bölge nüfusunun dörtte üç buçuğunun çiftçi olduğunun (Yeni Adım, 23 Teşrinisani 1929, s. 1) ve Meriç ile Karasu nehirleri arasında bu dönemde tek bir sanayi tesisinin bulunmadığının gözden kaçırılmaması gerekir. Bölgeye yerleştirilen göçmenler araziyle çiftçi adedi arasındaki oranı negatif yönde etkiledikleri gibi (Yeni Adım, 19 Mart 1929, s. 1), bölge Türklerinin yaşam koşullarının da Lozan Antlaşması öncesine göre kötüleşmesine sebep olmuşlardır (Yeni Adım Gazetesi, 10 Teşrinisani 1928, s. 1-2).

Gözden kaçırılmaması gereken bir diğer husus, bu dönemde Yunan idaresi tarafından Kayalar Çiftliği örneğinde olduğu gibi, Türklere ait bazı çiftlikler ve arazilerin istimlâk edildiğidir (Yeni Adım, 15 Haziran 1929, s. 4). Atmacalı, Köresten, Isıca, Makaklar, Keçiler, Emirli, Mustafçova, Ketenlik, Yassı̈ren ve Şahin köylerinde köylülerin ellerindeki tapular dikkate alınmaksızın Yunan Hükümeti tarafindan ormanlara el konulmuş ve Orman Dairesi'ne devredilmiştir. Sonrasında bu ormanlar kereste, kömür ve odun temin edebilmek üzere Hellen işletmecilere 
satılmıştır (Yeni Adım, 26 Mart 1929, s. 1). İstimlâk öncesi Balkan Kolu'nda yer alan bu köyler ormanlardaki ağaçların bir kısmından kömür ve odun, bir kısmından kereste elde edebiliyor ve hayvanlarını beslemek için yararlanabiliyorlarken, bunları gerçekleştiremez hale gelmişlerdir. Oysa bölgenin Balkan Kolu'nda geniş araziler söz konusu değildir ve taşlik arazilerde ancak tütün yetiştirilebilmektedir. Batı Trakya'nın bu bölgesindeki köylülerin hayatı daha ziyade ormanlara dayanmaktaydı ki, bunu bilen Mehmet Hilmi oldubittilere itirazını, "Bu köylüyü ormandan ayırmak demek, aç bırakmak demektir" cümlesi ile ifade etmiştir (Yeni Adım, 24 Teşrinievvel 1928, s. 1-2).

Savaş sonrası yıllarda belki ekonomik krizin de etkisiyle tütüne iyi birim fiyatları verilememiş ve bazen ürünler uzun süre üreticilerin ellerinde bekleyerek değerlerinden kaybetmişlerdir (Yeni Adım, 15 Mart 1930, s. 1; Yeni Adım Gazetesi, 29 Haziran 1929, s. 1). Oysa tütün, günümüzde de olduğu gibi bölge Türklerinin temel geçim kaynağıdır. 1920'li yıllarda koza fiyatları düştüğünden dolayı ipek böcekçiliği de tatmin edici olmamış, bağcılık ve meyvecilik ise pek bir gelir getirmemiştir (Benaki Müzesi, Eleftherios Venizelos Arşivi, 053-36). Diğer taraftan bölgeye mübadil yerleştirilmesi ile birlikte Yunan tüccarlar işletmelerinde mübadilleri tercih etmeye başlamışlardır. Mehmet Hilmi'nin “... Son günlerde ü̧̈ dört Türk dükkânı kapandı ve kapanmak üzeredir. Bu felaket esnafin fazla alacakl bulunmast ve umumi icranın tesiri neticesi olarak peşin parayla ciro edememesindendir..." cümlesiyle ortaya koyduğu gibi, çiftçi ile işçi sınıfının ekonomik yönden zayıflaması, geçimini bunlardan sağlayan bölge esnafının durumunun da kötüleşmesine yol açmıştır (Yeni Adım, 5 Nisan 1930, s. 2-3; Yeni Adım, 1 Nisan 1929, s. 1).

10 Haziran 1930 Ankara Sözleşmesi’yle (Düstur, 3. Tertip, Cilt 11, s. 1939-1966) Türkiye ile Yunanistan arasında nüfus mübadelesinden kaynaklanan birtakım sorunlar çözüme bağlanana kadar, Batı Trakya Türkleri için alım-satım yasaklanmıştır (Yeni Adım Gazetesi, 25 Kanunusani 1930, s. 1). Bu uygulama Batı Trakya Türkleri arasında mübadele edileceklerine dair şüphelere ve kaygılara sebep olduğu gibi, ekonomik krizin halkı fazlasıyla etkilediği bir dönemde bankaların emlak ve arazi karşılığında kredi açmasını, dolayısıyla halkın biraz rahat nefes almasını da engellemiştir (Yeni Adım Gazetesi, 21 Eylül 1929, s. 2; Yeni Adım Gazetesi, 12 Teşrinisani 1929, s. 3; Yeni Adım Gazetesi, 16 Teşrinisani 1929, s. 1). Bu duruma çelişki teşkil eder bir şekilde aynı dönemde Türkler askerlik yapmakta, seçimlere katılmakta, kısacası bir Yunanın yerine getirdiği tüm görevleri yerine getirmektedirler (Yeni Adım Gazetesi, 25 Kanunusani 1930, s. 1). Diğer taraftan bölge Türklerinin bir kısmının Yunanistan'ın Makedonya Bölgesi'nde, yani Batı Trakya'nın batı sınırının ötesinde oldukça önemli bir yekûn tutan emlak ve arazileri kalmıştır. Bu kitle içinde Balkan Savaşları akabinde arazilerinden ve Lozan Antlaşması akabinde emlaklerinden tek kuruş gelir sağlayamayanlar da yer almıştır (Yeni Adım Gazetesi, 21 Kanunuevvel 1929, s. 1; 4).

Stilianopulos 12 Temmuz 1929 tarihli raporunda hem Türklerin hem de Hellenlerin ekonomik birtakım kaygılarla kendisine başvurduklarından söz etmektedir. Türklerin kendisine başvurma sebebi alım-satım yasağından şikâyettir. Ancak Hellenler, Türklerin mülklerini satamamaları sebebiyle kendilerine olan borçlarını ödeyemediklerinden şikâyetçi olmuşlardır (Benaki Müzesi, Eleftherios Venizelos Arşivi, 053-34-35). 30 Eylül 1928 tarihli raporunda mübadelenin Batı Trakya Türklerinin ekonomisi üzerindeki negatif etkilerinden söz eden Stilianopulos, sıkıntılar sebebiyle tefeciliğin etkili olduğuna ve Batı Trakyalı Türk çiftçilerin üretimlerinden arttıramadıkları için birtakım çıkarcıların kurbanı olduklarına işaret etmektedir. Türklerin bir kısmının topraksız kaldıkları, ya da büyük borçlar altına girdiklerinden dolayı göç etmeye karar verdiklerini kaydetmekte, bunun yanında yerli ve göçmen Hellenlere tüm potansiyellerini harekete geçirerek daha fazla güçlenmeyi tavsiye etmektedir (Benaki Müzesi, Eleftherios Venizelos Arşivi, 053-36). Stilianopulos'un raporlarında düştüğü notlar, Batı Trakyalı Türklerin gelirlerinin 1920 ile 1922 yılları arasında pek farklı olmadığını, ancak 1922'den 1925'e gelindiğinde yüzde elli oranında ve ani bir şekilde azaldığını vurgulayan Mehmet Hilmi'yi doğrular niteliktedir. Mehmet Hilmi de çeşitli yazılarında Türk köylüsünün bu dönemde borç 
aldığına (Yeni Adım Gazetesi, 23 Teşrnisani 1929, s. 1) veya sermayesinden yediğine (Yeni Adım Gazetesi, 5 Nisan 1930, s. 2-3), ekonomik sıkıntıları öngöremediği için borcuna karşılık senetler imzaladığına, ne var ki borcunu zamanında ödeyemeyince bir de borcunun faizini yüklendiğine değinmiştir (Yeni Adım Gazetesi, 22 Mart 1930, s. 1).

\section{Haziran 1930 Ankara Sözleşmesi Sonrası Batı Trakya Türkleri}

10 Haziran 1930 Ankara Sözleşmesi'yle "Yunanistan, Batı Trakya'ya geldikleri tarih ve doğduklart yer ne olursa olsun değissimden ayrık tutulmuş olan Batı Trakya Bölgesi'nde hazır bulunan Yunan uyruğundaki tüm Müslümanlara” yerleşik sıfatını tanımıştır. Sözleşmenin 15. maddesiyle, yapılmış olan sözleşme ve anlaşmalarla yerleşiklere tanınmış olan hakların kullanımını engellemiş olan bütün tedbirlerin kalkacağı hükmü getirilmiştir. Bu haklar arasında özellikle arazi alım ve satımı da sayılmıştır. Sözleşmenin 22. maddesi uyarınca antlaşmalara aykırı olarak Batı Trakya Bölgesi'ne yerleştirilen mübadillere verilmek üzere Türklerin ellerinden alınan arazilerin sahiplerine geri verilmesi imkânsız ise, Karma Mübadele Komisyonu'nun bu imkânsızlığı tespit etmesiyle bu mallar Yunan Hükümeti'ne geçecek, Yunan Hükümeti bu malları tazmin edecektir. Sözleşmenin 29. maddesi ise mülkiyeti Yunan Hükümeti'ne geçmeyen malların, bundan böyle hiçbir sınırlama ve el koyma konusu olamayacağını ve sahiplerinin bu mülklerden istedikleri gibi istifade edebileceklerini hükme bağlamıştır (Düstur, 3. Tertip, Cilt 11, s. 1939-1966).

1930 Ankara Sözleşmesi ile Batı Trakyalı Türklerin durumunun netlik kazandığı söylenebilirse de Yunan arşivlerinde yer alan kimi belgeler, birtakım sıkıntıların 1930'lu yıllarda da devam ettiğini ortaya koyar niteliktedir. Örneğin Yunan meclisindeki Batı Trakyalı dört Türk milletvekili, Başbakan Venizelos ile Ekonomi ve Dışişleri Bakanlarına sundukları 3 Mart 1931 tarihli dilekçelerinde, Yunan Devleti'nin el koyduğu mülklere ilișkin kira ve tazminat bedellerini sürekli erteleyerek ödemediğinden şikâyet ederek, konunun adaletli bir şekilde çözümünü istemişlerdir. Söz konusu dilekçenin altında imzası bulunan dört Batı Trakyalı milletvekili Ali Galip, Niyazi Mumcu, Ali Rıza ve Halil Karaçanlı'dır (Benaki Müzesi, Eleftherios Venizelos Arşivi 235-23).

Trakya Genel İdarecisi Dimitrios Floryas'1n 15 Ekim 1932 tarihinde Trakya Temyiz Mahkemesi Başsavcısı'na (Benaki Müzesi, Eleftherios Venizelos Arşivi 113-24-26) ve 17 Ekim 1932 tarihinde Başbakan Venizelos'a (Benaki Müzesi, Eleftherios Venizelos Arşivi 113-24) göndermiş olduğu, bölge Türklerinin arazileri konusunda Yunan Devleti ile olan sorunlarına ilişkin yazılar, Ankara Sözleşmesi sonrası vuku bulmuş olan gelişmelere dair ciddi ipuçları sunmaktadırlar. Floryas, başsavcıya göndermiş olduğu yazısında, Batı Trakya'ya büyük bir mübadil nüfus yerleştirildiğini ve onlara halen bölgede ikamet eden veya göç etmiş olan Türklere ait toprakların verildiğini kabul etmektedir. Bu arazilerin bazılarının sahipleri ile anlaşılarak satın alındıklarına, bir kısmının ise devlet tarafından el konularak mübadillere dağıtıldıklarına ve bu durumun bölge Türkleri ile Yunan idaresi arasında "arazi sorunları" olarak nitelendirilebilecek sorunlar yarattığına işaret etmektedir. Ancak bizim açımızdan bu yazılarda çarpıcı olan, Floryas'ın bundan sonra naklettikleridir. Arazilerine ve mülklerine el konulmuş olan pek çok Türk, kimi avukatlara başvurmuşlardır. Arazilerin ve mülklerin iadesi veya bunlara karş11ık tazminat ödenmesi konusunu bakanlıklar, Trakya Genel İdaresi ya da yerel merciler nezdinde takip etmeyi üslenmiş olan bu avukatlar, hizmetleri karş1lığında Türklerle bazıları noter huzurunda olmak üzere özel anlaşmalar imzalamışlardır. Floryas'a göre iki ülke arasında mübadeleden kaynaklı sorunlara çözüm getirilmiş olup, bölge Türklerinin Trakya Genel İdaresi'ne veya Mübadele Karma Komisyonu'na başvurmaları halinde meseleleri Ankara Sözleşmesi uyarınca çözümlenmekte, bazen kendilerine arazi ve mülkleri iade edilmekte, bazen de bunlar için tazminat ödenmektedir. Ancak öncesinde arazileri ve mülkleri konusunu takip etmek üzere Türklerle anlaşmış olan avukatlar, birtakım kanunlardan ve yaptıkları anlaşmalardan yararlanarak onları mahkeme karşısına getirip ücretlerini ve mahkeme masraflarını talep etmişlerdir. Talep edilen ücretler çok yüksek olup, bazen Türkler avukatlara 
arazilerini terk etmek zorunda kalmışlardır. Esasen Floryas'1 harekete geçiren, Türklerin bu konudaki şikâyetlerini Karma Mübadele Komisyonuna taşımalarıdır. Şikâyetler üzerine söz konusu komisyon Trakya Genel İdaresi’ni yazı göndererek uyardığı gibi, komisyonun Türk üyesi Fuat Bey de bizzat ziyaret etmiştir. Avukatların bölge Türklerine karşı davranışının "şantaj" olarak isimlendirilebileceği kanaatinde olan Floryas, bu meselenin iki ülke arasında sorun teşkil edebileceğini düşünerek ve Türk basınındaki makaleleri de göz önünde bulundurarak konuya başsavcının ilgisini çekmeyi uygun görmüş, az sayıda kişinin kazancı uğruna Yunan idaresinin "dürüstlüğü ve güvenilirliğine" gölge düşmemesi gerektiğine işaret etmiştir. Floryas ayrıca mahkemelerin Türklere karş1 "iyi niyetli" ve "ilımlı" davranmalarını istemiştir. Benzer şekilde Venizelos'a gönderdiği yazısında da ekonomik olarak güçsüzlükleri sebebiyle avukatların talep ettiği yüksek ücretleri ödeyemeyen Türklerin bölgeyi terk etmek zorunda kaldıklarına ve konuya bir çözüm yolu bulunması gerektiğine dikkat çekmiştir.

Esasen üst paragrafta işaret ettiğimiz Floryas'1n yazıları, kanaatimizce 1923-1930 arası dönemde Batı Trakya Türklerinin içine düştüğü çaresizliğin ve meselelerin çözümünün gecikmesi ve içinde bulundukları ekonomik darlık sebebiyle paniğe kapılarak birtakım firsatçıların ağına düştüklerinin kanıtıdır. Nitekim Floryas'ın Venizelos'a gönderdiği 6 Ekim 1932 tarihli telgrafta da Batı Trakya Türklerinin konumları belli bir zemine oturduktan sonra dahi Türkiye'ye göç etmeye devam ettikleri dile getirilmiştir. Telgraftan göçün özellikle ekonomik sebeplerle vuku bulduğu ve göç edenlerin yaz aylarında suları azaldığında, ıssız noktalardan Meriç’i geçtikleri anlatılmıştır (Benaki Müzesi, Eleftherios Venizelos Arşivi 1139).

Şunu da ifade etmeliyiz ki mübadeleden sonraki yıllarda da Türk arazilerinin istimlâk edilerek topraksız Yunan halkına dağıtılmasına devam edilmiştir. Örneğin 1539/1938 sayılı yasanın 34. maddesi ile "vekil bırakmadan Yunanistan'ı terk eden kişilerin mülklerinin hükümet tarafindan yönetilmesi" öngörülmüş ve çeşitli nedenlerle Batı Trakya'yı terk etmiş Türklerin arazileri bu hüküm uyarınca hazine malı addedilmişlerdir. 821/1948 sayılı Arazi Birleştirmesi Yasas1 uyarınca, bölgede yaşanmış olan savaşlar neticesi kamu binalarının zarar görerek resmi evrakların kaybolması neticesi senet ibraz edemeyen bölge Türklerinin binlerce dönüm arazisi devlete intikal etmiştir. 2185/1952 sayılı yasa uyarınca istimlâk edilen Türk çiftliklerinin başında Büyük Kaval, Küçük Kaval, Kara Musa, Anaköy, Ilgın, Tepe, Koç Obası, Ferezler, Kalfalar ve Küçük Osmanlı çiftlikleri gelmektedir. İstimlâk edilen arazi on binlerce dönüme ulaşmaktadır. Günümüze değin bu tip uygulamaların onlarca örneği verilebilir. Netice itibarıyla 1923 'te bölge arazisinin \%84'ü Türklerin elindeyken, Türklere ait arazilere gerçekleştirilen istimlâklerle bu oran günümüzde \%25'lere kadar düşmüştür (Chairoula, 2018, s. 197-200).

\section{Batı Trakya Türklerinin, Lozan Antlaşması ve Mübadele Protokolünden Kaynaklı Kimlik Sorunları}

Lozan Antlaşması'nın "Azınlıkların Korunmasına” ilişkin hükümlerinde, Batı Trakya Türkleri dini kimlikleri ile "Müslüman" olarak ele alınmışlardır. Antlaşmanın 45. maddesinde "işşu kesim hükümleri ile Türkiye'nin Müslüman olmayan azınlıkları için tanınan haklar, Yunanistan tarafindan da, kendi topraklarında bulunan Müslüman azınlı̆̆a tanınmıştır" denilmektedir (Soysal, 2000, s. 103-106). Bu esasen toplumu Müslümanlar, Rumlar, Ermeniler ve Yahudiler olarak sinıflandıran Osmanlı "Millet Sistemi”nden arda kalan bir alışkanlıktır (Kurtaran, 2011, s. 61). Tüm Balkan coğrafyasında yaşayan Müslümanların, İslam dini vasıtasıyla kendilerini Türklerle özdeşleştirdikleri de bir gerçektir (Koyuncu, 2013, s. 144). Lozan Antlaşması'na ek olarak imzalanmış olan "Türk ve Rum Nüfusun Mübadelesine İlişkin Sözleşme ve Protokol”da da İstanbul'da oturan Rumlarla Batı Trakya'daki Müslümanların mübadele dışında tutulacakları hükme bağlanmıştır (Soysal, 2000, s. 185). Oysa mübadele kapsamı dışında tutulanlara verilen "Etabli Belgeleri” üzerinde "Türk" sözcüğüne yer verilmiştir. Etabli Belgeleri, Mübadele Karma Komisyonu'nun görevde bulunduğu süre içinde mübadele kapsamı dışında tutulanlara verilen belgelerdir. Mübadele dışında tutulanlar, ayrıca nüfus kütüğ̈ mahiyetindeki defterlere de 
kaydedilmişlerdir. Batı Trakya'da yerleşik olduğunu ispatlamak isteyen azınlık mensupları, Gümülcine'deki Türkiye Başkonsolosluğu'na başvurarak, "Türklük Belgesi” olarak andıkları bu belgeyi alabilmektedirler (Eren, 1995, s. 57-62).

Yunan idaresi, Lozan Antlaşması ve Mübadele Protokolünde Batı Trakya'daki azınlıktan "Müslümanlar" olarak söz edildiğinden dolayı, Batı Trakya Türklerinin etnik kimliğini zikretmeyi ve tanımayı istememektedir. Dikkatlice bakıldığında bu konudaki çelişkileri de saptanabilmektedir. Örneğin Batı Trakya Türklerinin ilk derneği, "İskeçe Türk Gençler Yurdu" ismiyle kurulmuş (İskeçe Türk Birliğii, 2003, s. 17; 23) ve dernek tüzüğü 1927 yılının Temmuz ayında İskeçe mahkemesi tarafından onaylanmıştır (Yeni Adım, 31 Ağustos 1929, s. 1-2; 4). 11 Mayıs 1930'da İskeçe Türk Gençler Yurdu'nun kurucu üyelerinden bir kısmı “Türk Ocağı" adı altında bir dernek kurmuşlardır. "İskeçe Türk Birliği" tüzüğünün 8. maddesinde derneğin amac1, "Batı Trakya Türklerinin ruhi, bedeni ve manevi eğitimlerine çalışmak, aralarında içten dostluk bağları ve dayanışma meydana getirmek, Türk inkılabının yarattı̆̆ kültürel, toplumsal ve dini yenilikleri Batı Trakya Türkleri arasında yaymak" olarak belirtilse de kuruluşu İskeçe Mahkemesi tarafından 17 Kasım 1936'da onaylanmıştır (http://www.iskeceturkbirligi.org/page.php?ref=tuzuk). Benzer şekilde "Gümülcine Türk Gençler Birliği” ve "Türk Öğretmenler Birliği” derneklerinin kuruluşları da gerçekleștirilebilmiştir (Eren, 1995, s. 87). Oysa söz konusu dernekler "Yunanistan'da Türk değil, Müslümanların var olduğu” gerekçesiyle 1983 yılından itibaren kapatılmışlardır (Chairola, 2018, s. 191). 1981 y1lından itibaren Avrupa Birliği üyesi olan Yunanistan'da, günümüzde isminde "Türk" kelimesi yer alan derneklerin kurulmasına izin verilmediği gibi (Gündem, 16 Nisan 2005, s. 3), Avrupa İnsan Hakları Mahkemesi'nin derneklerin konu ile ilgili başvurularına yönelik kararları da uygulanmamaktadır (Gündem, 13 Aralık 2013, s. 3).

3065/1954 sayılı "Batı Trakya Türk İlkokullarının Kuruluş ve Faaliyet Şekli ile Bunların İdarecilerini ve Batı Trakya Türk İlkokul Müfettişlerini İlgilendiren Bazı Maddelerin Düzenlenmesi Hakkındaki Kanun Hükmündeki Kararname" ile bölge Türklerinin etnik kimliğini tanıyan Yunanistan'da (Chairoula, 2018, s.88), 1966 yılına kadar Türklere ait ilkokullarda "Türk İlkokulu” ibaresi yer almıştır (Şerif, 1999, s. 382). 1968 Türk-Yunan Kültür Komisyonu, Atina ve Ankara toplantılarında azınlık fertlerinin din, 1rk ve milliyet şuuruna saygı gösterilmesini tavsiye etmiş ve 1968'e kadar azınlık dilinde (yani Türkçe) okutulan derslerin, bundan sonra da istisnasız yine azınlı dilinde (Türkçe) yapılacağını bildirmiştir (https://gtgb.gr/brosurler/ankara_atina_protokolu.pdf).

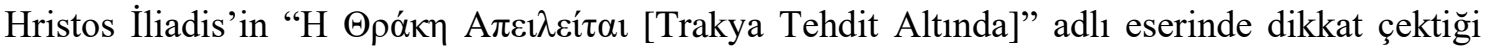
üzere Yunan mercileri kamuoyu karşısında Batı Trakya'daki azınlıktan "Müslüman" olarak söz ederken, kendileri ile çelişir bir şekilde pek çok gizli belgede "Türk" olarak bahsetmișler ve daha da önemlisi "Türk muamelesi” yapmıșlardır (İliadis, 2018, s. 78-79). Șunu da belirtmeliyiz ki Yunan idaresi, Türkiye'deki inkılapların Batı Trakya'da da benimsenmesi halinde azınlığın ulusal bilincinin güçleneceğinden korkmuştur (Panayotidis, 1995, s. 151). Örneğin bu sebeple Bat1 Trakya Türklerine ait okullarda "Yeni Türk Alfabesi"ne geçilmesini, "Ankara'nın sembolü" ve "Türkiye'de üretilecek kültürel ürünlerle temasa geçmenin aracl" olarak gördüğünden dolayı geciktirmeye çalışmıştır (Yeni Adım, 27 Teşrinievvel 1928, s. 1).

Kısaca özetlemeye çalıştı̆̆ımız Batı Trakya Türklerinin kimlikleri ile ilgili sorunları 1920'lerden 2020'lere yüz yıldır devam etmektedirler. Batı Trakya Türklerinin kimlikleri ile ilgili yaşadıkları problemler, 1970'li yıllardan itibaren Kıbrıs Sorunu'na paralel tırmanışa geçmiştir (Oran, 1986, s. 106). Bugün Batı Trakya'daki azınlık Yunan idaresi tarafından "Türk Kökenliler (Turkogenis)", "Pomaklar" ve "Çingeneler" olarak alt gruplara ayrılarak ele alınmaktadır (Panayotidis, 1995, s. 228). 


\section{SONUÇ}

Şüphesiz göç, göç eden kitleyi derinden etkilemekte, maddi ve manevi olarak kayıplarına sebep olmaktadır. Göç eden birinci nesil, hele ki ilerlemiş bir yaşta ise geldiği yere uyumda son derece zorlanmakta ve doğduğu toprakları özlemektedir. Bazen buna, geldiği yerde aradığını bulamamanın verdiği sıkıntılar da eklenmektedir. Üstelik mübadele zorunlu bir göçtü. Bir diğer ifadeyle mübadeleye tabi olanların "ben gitmek istemiyorum" deme şansı bulunmuyordu. Her iki ülkeyi de demografik, sosyal, ekonomik ve kültürel olarak derinden etkilemiş olan mübadele konusu, bu sebeplerden dolayı günümüze değin Türkiye ve Yunanistan'da hikâye ve romanlara konu olmuş, her iki ülkede de hakkında filmler yapılmıştır.

Göçten, göçmenlerin yerleştirildikleri bölgeler de etkilenmektedir ki, Batı Trakya bölgesi buna son derece iyi bir örnek teşkil etmektedir. Yunanistan, Türkiye'ye sınır olan bir bölgede, büyük bir Türk nüfusun yaşamasından duyduğu kaygılar sebebiyle olsa gerek, Batı Trakya bölgesine kapasitesinin çok ötesinde mübadil yerleştirmiştir. Mübadil yerleştirme işlemi bölgenin demografik yapısını değiştirecek şekilde gerçekleştiği gibi, bölge ekonomisini de olumsuz yönde etkilemiştir. Daha da önemlisi Türklere ait bazı arazi ve mülkler el değiştirmiştir. Buradan hareketle mübadil yerleştirilmesinin, bölgede kökten değişimlere sebep olduğunun altını çizmemiz gerekir.

Yunanca bilmeyen, muhafazakâr yapıda olan ve Hıristiyan komşuları ile evleri, yatakları ve yorganları başta olmak üzere her şeylerini paylaşan bölge Türkleri, başlarda bu yan yana yaşamı sürdürmekte zorlanmışlardır. Bazı yerleşim birimlerinde birtakım asayiş problemleri de yaşanabilmiştir. Ancak bu ilişki her zaman sıkıntılı olmamış, çoğu zaman kalıcı dostluklar da geliştirilmiştir. Esasen son derece uysal karakter taşıyan bölge Türkleri, yeni koşulları gögüslemek için ellerinden gelen gayreti göstermişlerdir. Yine de yeni koşullara uyum sağlayamayanlar Türkiye'ye göç etmeyi yeğlemişlerdir. Bu göçün en temel sebebi ekonomik olup, bu dönemde yaşadıkları darlık ve umutsuzluk sebebiyle birtakım fırsatçıların ağına düşenler de olmuştur. Batı Trakya örneğinde bir göç, başka bir göçü tetiklemiş̧tir.

Lozan Antlaşması ve Mübadele Protokolünden, Batı Trakya Türklerine bir de kimlik problemi kalmıştır. Lozan Antlaşması ve Mübadele Protokolünde dini kimlikleri ile ele alındıklarından dolayı Yunanistan, Batı Trakya'daki azınlığın etnik kimliğini tanımak istememektedir. Batı Trakya Türklerinin bu sorunu, arazi ve mülklerinin istimlak edilmesi sorunu gibi yüz yıldan beri devam eden bir sorundur.

\section{KAYNAKÇA}

\section{Arşivler}

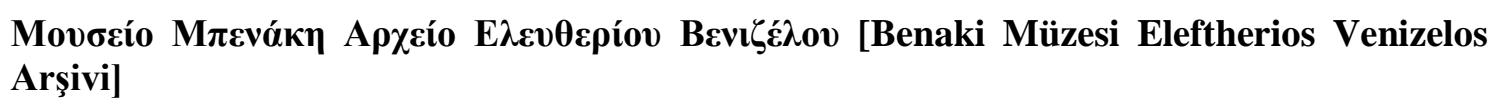

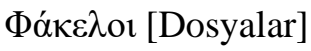

053-34-35 053-36 113-9 113-24 113-24-26

235-23 251-27

\section{Resmi Yayınlar}

Düstur, 3. Tertip, Cilt: 11. 


\section{Türkçe Kitap, Makale ve Bildiriler}

Alp, İ. (1995). Batı Trakya Türkleri. Atatürk Araştırma Merkezi Dergisi, Cilt: X, Sayı: 33, ss. 623-652.

Anı ve Hikâyeleriyle Mehmet Hilmi (2021). R. Ali (Yay. Haz.). Ksanthi: BAKEŞ Yayınları.

Arı, K. (1991). Mübadele Göçmenlerini Türkiye’ye Taşıma Sorunu ve İzmir Göçmenleri (19231924). Çağdaş Türkiye Araştırmaları Dergisi, Cilt: 1, Sayı: 1, ss. 13-46.

Arı, K. (2014). Büyük Mübadele (6. Baskı). İstanbul: Tarih Vakfı Yurt Yayınları.

Bayındır Goularas, G. (2012). 1923 Türk-Yunan Nüfus Mübadelesi ve Günümüzde Mübadil Kimlik ve Kültürünün Yaşatılması. Alternatif Politika, Cilt: 4, Sayı: 2, ss. 129-146.

Bıyıklığlu, T. (1955). Trakya'da Milli Mücadele. Ankara: Türk Tarih Kurumu Basımevi.

Budak, M. (2014). Misak-1 Milli’den Lozan’a (5. Bask1). İstanbul: Küre Yayınları.

Cihan, S. S. (ty). Balkan Savaşı ve 1913 Batı Trakya Türk Cumhuriyeti. İstanbul: Yeni Batı Trakya Dergisi Yayınları.

Erdem, N. (2014). 1913 Yılının Temmuz-Ekim Ayları Arasında Batı Trakya Türkleri İle İlgili Gelişmelerin Yunan Basınındaki Yansımaları. History Studies, Cilt: 6, Sayı: 2, ss. 67-89.

Erdem, N. (2018). Efemera Ürünlerin Işı̆̆ında 1920'lerin Gümülcine'sinde Bir Genç: Gayrimübadillerin Fotoğrafçısı Ahmet Mehmet (Hamdi). C. Eraslan, N. Erdem, C. Bayram (Ed.), Balkanlarda Türk Kültürü: Batı Trakya Uluslararası Sempozyumu Bildiriler (ss. 102-115). İstanbul: Türk Ocakları İstanbul Şubesi Yayını.

Gazi M. Kemal (1999). Nutuk (Cilt: II). Ankara: Türk Tarih Kurumu.

Gencer, A. İ., Özel, S. (2001). Türk İnkılap Tarihi (8. Basım). İstanbul: Der Yayınları.

Hüseyinoğlu, T., İmamoğlu, M. (2017). Yunanistan'da Başmüftülük, Müftülükler ve Müftüler (1913-2014). Ksanthi: BAKEŞ Yayınları.

İnönü, İ. (1987). Hatıralar (2. Kitap). Ankara: Bilgi Yayınevi.

İskeçe Türk Birliği (2003). Ksanthi: İskeçe Türk Birliği Yayını.

Koyuncu, A. (2013). Balkan Savaşları Sırasında Pomakların Zorla Tanassur Edilmesi (19121913). OTAM, Cilt: 33, Say1: 33, ss. 139-196.

Kurtaran, U. (2011). Osmanlı İmparatorluğunda Millet Sistemi. Sosyal Bilimler Enstitüsü Dergisi, Sayı: 8, ss. 57-71.

Oran, B. (1986). Türk Yunan İlişkilerinde Batı Trakya Sorunu. Ankara: Mülkiyeliler Birliği Vakfı Yayınları.

Soysal, İ. (2000). Türkiye’nin Siyasal Andlaşmaları (Cilt: I). Ankara: Türk Tarih Kurumu.

\section{Yunanca Kitaplar}

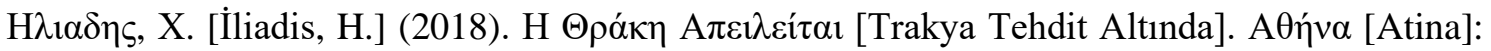

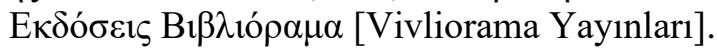




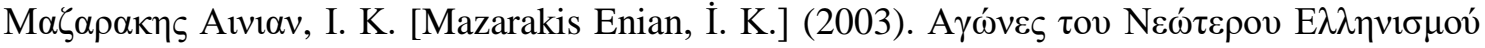

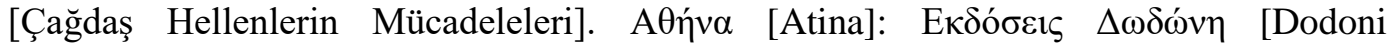
Yayınlar1].

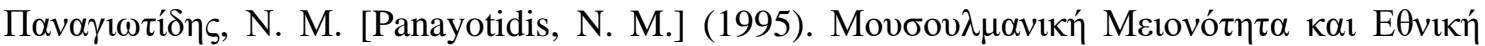

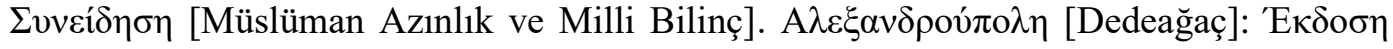
TE $\triangle K$ N. 'E $\beta \rho o v$ [Meriç Vilayeti TEDK Yayını].

\section{Tezler}

Chairoula, P. (2018). Balkan Savaşlarından Sonra Batı Trakya Türklerinin Sosyo-Kültürel Hayatı ve Eğitim Tarihi (Yayımlanmamış Doktora Tezi). Trakya Üniversitesi, Sosyal Bilimler Enstitüsü, Edirne.

Eren, H. (1995). Batı Trakya Türkleri (Yayımlanmamış Doktora Tezi). Marmara Üniversitesi, Sosyal Bilimler Enstitüsü, İstanbul.

Pavlidis, A. (1997). Yunan Kaynaklarına Göre Mübadele Meselesi (Yayımlanmamış Yüksek Lisans Tezi). İstanbul Üniversitesi, Sosyal Bilimler Enstitüsü, İstanbul.

\section{Gazeteler}

Gündem

Yeni Adım

\section{İnternet Kaynakları}

http://gtgb.gr/brosurler/ankara_atina_protokolu.pdf

http://www.iskeceturkbirligi.org/page.php?ref=tuzuk 


\section{EKLER}

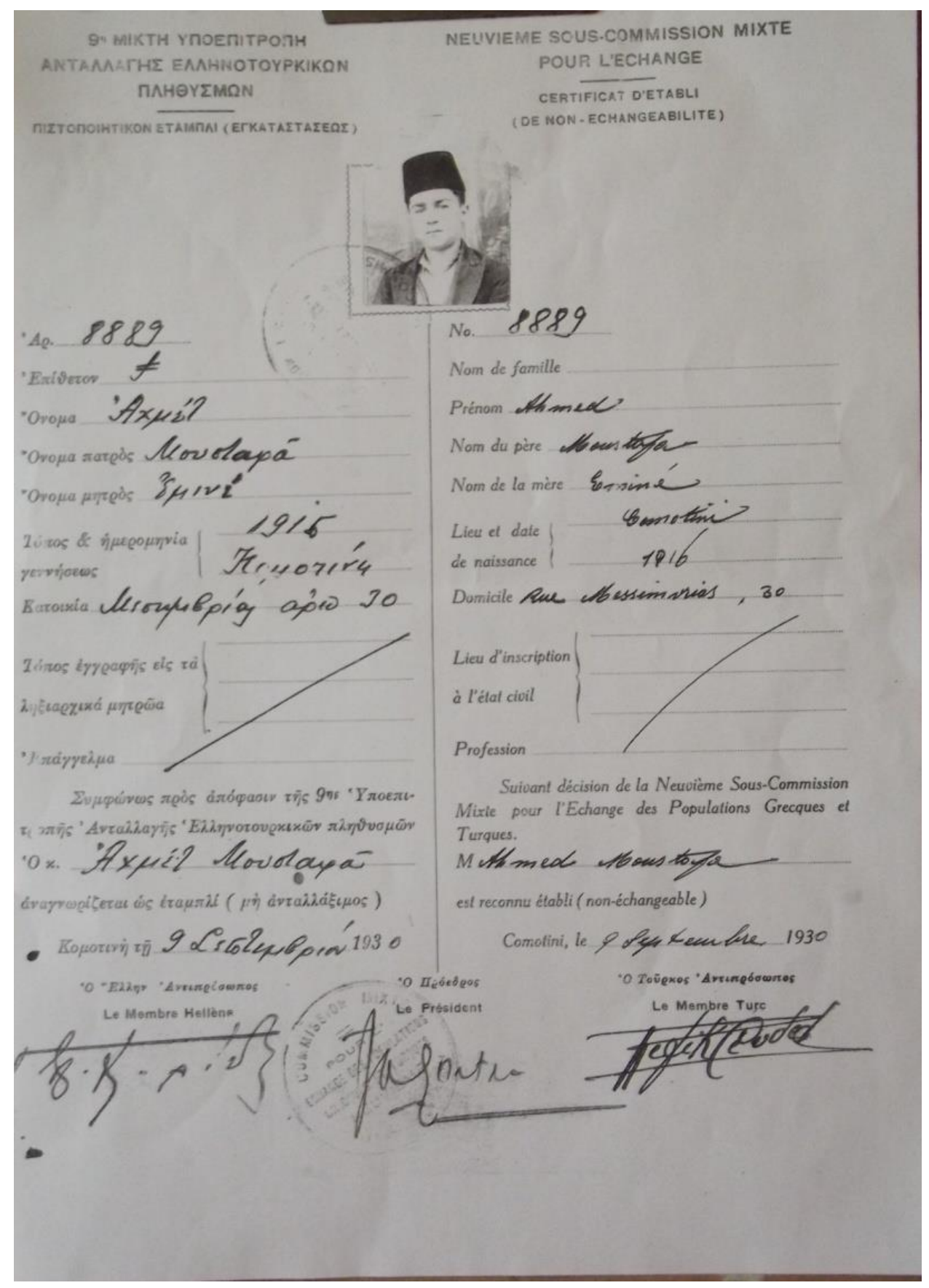

EK 1. Bir Batı Trakyalı Türk’e Ait "Etabli Belgesi" 